Central Washington University

ScholarWorks@CWU

Anthropology and Museum Studies Faculty

Scholarship

College of the Sciences

Spring 2020

The Making and Unmaking of an Appalachian "Home": Tensions between Tourism and Housing Development in Gatlinburg, Tennessee

J. Hope Amason

Follow this and additional works at: https://digitalcommons.cwu.edu/anthropology_museum_studies

Part of the Appalachian Studies Commons, Social and Cultural Anthropology Commons, and the Urban Studies and Planning Commons 


\title{
The Making and Unmaking of an Appalachian "Home": Tensions between Tourism and Housing Development in Gatlinburg, Tennessee
}

\author{
By J. Hope Amason
}

This article examines the economic and symbolic dimensions of redevelopment in Gatlinburg, Tennessee. I focus on one particular project, the East Parkway at Baskins Creek Bypass District, which concerned ten acres that contained a vital housing resource for low-income tourism-industry workers: residential motels. I connect Gatlinburg's housing crisis with changing labor patterns in the wake of economic restructuring. I present two letters submitted by real estate developers and solicited by the City of Gatlinburg. In analyzing the letters, I identify two tensions: (1) between workers' homes and the aesthetics of "Appalachian" tourism, and (2) between representations of workers and the diverse realities of workers' lives. I conclude by arguing that solutions addressing housing alone-without also considering tourism-industry labor patterns, including fluctuating wageswill ultimately fall short of accomplishing affordable housing for Gatlinburg's residential workforce.

Gatlinburg, a town in Sevier County, Tennessee, with a population of 3,944 , hosts approximately eleven million tourists per year and is a gateway community to the most visited national park in the United States, the Great Smoky Mountains (US Census Bureau 2010). ${ }^{1}$ Since the park's opening in 1934, Gatlinburg has experienced rampant, unregulated commercial tourism that has produced a patchwork of incongruent styles within the built environment. In 2008, the City addressed this visual disjuncture by publishing architectural guidelines that encouraged business owners and developers to cultivate a "mountain village aesthetic that is deeply rooted in the culture and history of the southern Appalachians" (City of Gatlinburg 2008, 1). ${ }^{2}$ Using log siding, native stone, and colors that draw upon the surrounding forests and mountains, many businesses in Gatlinburg's downtown tourism corridor have been redesigned in order to evoke the aesthetic of small town, pre-industrial "Appalachia."3 Tourists are encouraged to see Gatlinburg as a familiar, even familial, place—a home away from

J. Hope Amason is Associate Professor of Anthropology and Museum Studies at Central Washington University. 
home. "The mountains are calling," announces Gatlinburg's 2017 vacation guide, which portrays Gatlinburg as "the kind of place that brings families together, where memories are made around every corner" (Gatlinburg Convention and Visitors Bureau 2017, 1).

While Gatlinburg markets itself as an "Appalachian" homeland for tourists, home is a much more contentious issue for the thousands of low-wage service workers whose labor is needed to profitably run restaurants, lodgings, amusements, and retail spaces. A housing shortage for Gatlinburg's low-income workforce has plagued the town's tourism-based economy for decades. Many low-income residents live in weekly rental residences, which have become Gatlinburg's most affordable housing option (Amason 2015; Smith 1989; Kennedy, Coulter, Rushing, and Watson, LLC 2008; Farrell 2009). A number of these weekly rentals are dilapidated tourist motelsbuilt in the mid-twentieth century for overnight lodgers-now functioning as permanent homes.

Tourism forces sharp contradictions between the front-stage spaces of touristic consumption, where "Appalachia" is marketed and sold, and back-stage spaces, where low-income workers reside, often in substandard housing. When these contradictions are mapped onto the Gatlinburg landscape, an image of uneven development emerges, wherein neighborhoods of poverty exist in tension with sites for the production of capital within the tourism industry. To say that development is "uneven" is not merely to describe the income and wealth inequality present within a given geographic area. Rather, "uneven development" is a relational process by which capital accumulation restructures spatial relations, "the geographical expression of the more fundamental contradiction between use-value and exchange-value" (Smith 2008,6). There are few places where this contradiction is more emotionally heated, or more personally relevant, than in housing (Harvey 2014). On a symbolic level, the contradiction between Gatlinburg's front-stage spaces and the weekly rental homes that serve as its back-stage spaces is a conflict over belonging. To draw on a classic anthropological concept, this is a debate about matter (in this case, people and their homes) that is seen as being "in" or "out" of place (Douglas 1966). On a structural level, however, this contradiction is an outcome of an inherent relationship wherein the production of profits for the tourism industry is accomplished by producing poverty in the form of low wages and high rents.

Classic studies of Appalachian uneven development have identified regional dynamics within the United States and the global market economy as factors contributing to the production of poverty at multiple scales (Lewis, Johnson, and Askins 1978; Gaventa 1980; Gaventa, Smith, and Willingham 1990; Billings and Blee 2000; Eller 2008). More recent scholarship on uneven 
development in Appalachia focuses on the effects of deindustrialization, specifically the declining employment within extractive industries, such as coal. It asks us to envision what a transition to a new, hopefully more "even" Appalachia might look like (Taylor, Hufford, and Bilbrey 2017; Tarus, Hufford, and Taylor 2017). Tourism has been identified as a possible growth area (Eller 2008; Fritsch and Johannsen 2004; Martin 2007). However, these same authors acknowledge that rampant tourism development can produce patterns of unevenness akin to the "resource curse" of extraction-based economies. Furthermore, tourism can lead to the reification of Appalachian culture and identity-in ways that do violence to the complicated and diverse realities of Appalachian places and peoples (Obermiller and Maloney 2016).

This article presents a case study that serves as an example of the processes of uneven development in Gatlinburg: the East Parkway at Baskins Creek Bypass District, a development project proposed by the Gatlinburg Housing and Redevelopment Authority (GHRA) in order to address "blighted areas" located along a main tourism corridor (City of Gatlinburg 2016, 7). This research emerges from ethnographic fieldwork (semi-structured interviews and participant observation) in Gatlinburg from 2007-2008, and in the summers of 2014, 2015, and 2016. Additionally, I have drawn from quantitative data made available by the US Bureau of Labor Statistics (BLS) in order to understand the economic transformations that continue to shape Gatlinburg's housing needs. With regard to research on the specific redevelopment plan addressed in this article, I closely read the GRHA document "East Parkway at Baskins Creek Bypass District: Redevelopment Plan Project 1" (City of Gatlinburg 2016), as well as proposals solicited from two commercial developers, LHP Capital, LLC (2016) and Atlantic Land (2016). Finally, I have made use of accounts from the local newspaper, the Mountain Press, regarding housing issues and the reception of this specific redevelopment proposal.

I begin by drawing a connection between Gatlinburg's housing crisis and changing labor patterns in the wake of economic restructuring. I show how Gatlinburg's tourism-industry workers are not "seasonal" employees, but rather that they experience seasonal underemployment, which significantly impacts housing affordability throughout the year. Next, I present two letters of interest submitted by real estate developers and solicited by the City of Gatlinburg. I reveal two tensions within these letters: first, between the "mountain village aesthetic" (LHP Capital 2016, 51; City of Gatlinburg 2008, 1) and workers and their homes, and, second, between the diverse realities of workers' lives and the discursive production of the "lowincome tourism-industry worker." I argue that the structural invisibility of Gatlinburg's low-income workforce prevents real estate developers-and 
the City-from understanding the complexities that shape workers' housing needs. In the midst of completing the research for this article, a wildfire consumed many homes and businesses in Gatlinburg, and I describe the impact the fire had on housing in the immediate aftermath. I conclude by arguing that solutions addressing housing alone-without also accounting for the everyday realities of tourism-industry labor patterns, including seasonal underemployment-will ultimately fall short.

\section{Context: Gatlinburg's Shifting Labor Regimes and the Affordable Housing Crisis}

Gatlinburg's housing crisis is not a new phenomenon. Housing shortages among service-industry workers in Sevier County were documented in the 1980s (Smith 1989). Residential motels, intended for temporary occupation, have been serving as permanent residences for many low-income workers in Gatlinburg. At \$125 to \$275 per week—with no lease, deposit, or utility payments-such by-the-week rentals are a tactic for mitigating economic uncertainty that provides some measure of affordability and freedom from liability (Amason 2015). This is particularly true for residents whose wages fluctuate drastically as a result of seasonal changes in Gatlinburg's tourism industry.

Winter is typically the "slow season," and can be a time of severe economic hardship for low-wage tourism-industry workers. In the early 1990s, for example, workers might have been laid off during the winter months. Bureau of Labor Statistics Local Area Unemployment data for Sevier County (1990-1995) shows the monthly unemployment rate fluctuating from 19.5 percent in January 1992 to as little as 3 percent in August 1994, with an average fluctuation for the entire five-year period of 14.34 percentage points (US Bureau of Labor Statistics 2017). This resonates with a 1989 study of poverty in Sevier County, funded by the Southeast Women's Employment Coalition, where tourism-industry employees "worked intensively for long, arduous hours six months out of the year," but were laid off during the slow, winter months, with many drawing unemployment insurance (Smith 1989, 48).

However, since the mid-1990s, the winter unemployment rate has become much smaller, with an average fluctuation of only 5.03 percentage points between 2012-2016 (US Bureau of Labor Statistics 2017). Time-share may be a factor in this, as it has temporally altered Gatlinburg's tourism industry by expanding the season well into the winter months. This trend is also evident at the level of ethnography. There are more tourists in Gatlinburg during the winter, as compared to the 1980s and early 1990s-however, they are still fewer than in the summertime. My field notes from early November 2007 are filled with accounts of the uncertainties facing 
workers and their employers. One souvenir shop owner acknowledged: "We haven't ever had to completely close down like some of these places do, but we have cut back hours." In 2007-2008, workers didn't necessarily fear being laid off, but were instead afraid that their hours would be significantly decreased during the winter, that they would need to find a second or even third job. Rather than seasonal unemployment, it is more accurate to call what occurs in the winter months "seasonal underemployment." Not knowing how many hours one will receive week-to-week can make it hard to predict future income, which is particularly relevant when signing a long-term housing lease.

Further complicating this dynamic is the presence of employees who come to Gatlinburg under the auspices of the J-1 Summer Work Travel visa, a federal program wherein US-based sponsorship agencies work with local employers to acquire temporary work visas for foreign youths. J-1 summer travel workers are a reliable pool of cheaper labor, as compared with local workers. Their employers do not have to pay payroll taxes, producing a savings of around 8 percent per worker (Southern Poverty Law Center 2014). Before each summer season begins, Gatlinburg employers may work with residential motel owners in order to secure housing for J-1 summer travel workers. This can make the housing market more competitive for local workers.

Gatlinburg's tourism industry, with its narrow profit margins and seasonal uncertainties, is made viable by the presence of weekly rental residences (often residential motels). Residential motels help occupants maintain personal dignity as well as physical and mental health, curbing a potential increase in homelessness. However, this doesn't mean they are affordable or safe. For local workers, residential motels can be very expensive relative to earnings. In 2015, Sevier County hospitality workers only made an average of $\$ 468$ per week (Johnson 2016), while residential motels can cost up to $\$ 1,000$ per month. Additionally, paying by the week-rather than the month-means residents receive less protection from abusive landlords. Finally, some motels violate housing code standards: The City of Gatlinburg cited one motel owner several times, ultimately condemning all or parts of their motels (Farrell 2016). Other motels do appear to meet standards, but they do not have a kitchen and often lack other safety requirements necessary for being zoned as long-term residences.

In 2016, the City of Gatlinburg attempted to address the problem of workforce housing through redevelopment projects, beginning with the East Parkway at Baskins Creek Bypass District. Yet this plan did not address the complex array of circumstances that make weekly renting a more "flexible" lifestyle choice: a contingent workforce, fluctuating wages, and seasonal underemployment. When the plan was unveiled, there were negative 
reactions among motel owners, their renters, and other residents and business owners located in the redevelopment district. Their comments revealed fears of losing familial land, assumptions that redevelopment would only benefit tourists, and dismay over language that described some properties as blighted.

\section{Reacting to Redevelopment: The Symbolic Violence of Blight}

On the evening of Thursday, February 25, 2016, Gatlinburg's city hall was packed, with standing room only (Neil 2016). The audience was there to hear from David Hill, a consultant hired by the City of Gatlinburg, in order to facilitate the East Parkway at Baskins Creek Bypass District redevelopment plan. Hill—who served on the advisory committee for Knoxville's South Waterfront Plan, which has transformed three miles of that city's shoreline along the Tennessee River-was there to answer questions and listen to concerns. Although Gatlinburg city officials, commissioners, and members of the newly formed GRHA were also present, Hill was the only representative on behalf of the City to speak at length.

Anxious citizens who would be affected by the proposal were not so quiet, however. A massage therapist at Fox Place Salon, located in the middle of the proposed redevelopment district, asked Hill: "What are you going to do for the residents who make the tourism possible? More pancake houses? Another distillery?" (quoted in Neil 2016). The owner of Fox Place, Robin Floyd, pointed out that the land had been in her family for over two hundred years: "Our land is still in the family and should remain so" (quoted in Neil 2016). These property owners, residents, and employees voiced their worries not only about the redevelopment project itself but about the designations of "blight."

Six properties in the redevelopment district map were marked in red, which indicated "blighted conditions observed" (City of Gatlinburg 2016). According to the Tennessee Code, "blight" is defined as

areas ... with buildings or improvements which, by reason of dilapidation, obsolescence, overcrowding, faulty arrangement or design, lack of ventilation, light and sanitary facilities, excessive land coverage, deleterious land use or obsolete layout or any combination of these or other factors are detrimental to the safety, health, morals or welfare of the community. (Tennessee Code, Section 13-20-201)

Labeling these properties as "blight" and placing them in the context of a redevelopment plan enabled the City of Gatlinburg to use eminent domain to acquire the land and sell it to commercial developers at a price determined by the GRHA. ${ }^{4}$ Four of the six blight-designated properties were motels: Ogle's Vacation Motel, Willow Motel, the Rainbow Motel, 
and Gatlinburg Village. Additionally, two other non-blighted motels-Red Carpet Inn and Spruce Flats Motel - were also located in the redevelopment district.

The symbolic association between properties characterized as "blight" and the homes of low-wage workers in the tourism industry did not escape the notice of residents and property owners within the redevelopment district. On one level, "blight" is an aesthetic judgment, a designation for matter that is deemed "out of place" (Douglas 1966). When governments and developers label properties as "blight," or promote a specific aesthetic using architectural guidelines, they are making statements about who and what belongs in a given area. We could understand this as a form of "aesthetic governmentality," a way of policing and managing the look of a space-particularly a city (Ghertner 2015). As with governmentality, aesthetic governmentality renders spaces knowable, quantifiable, and predictable. Residential motels-with their constant seasonal flow of service workers moving in and out, often with little-to-no documentation or evidence they were ever there-challenge any attempt to categorize, record, and understand.

What fills this gap in knowledge? Assumptions about people and the spaces they occupy. Implicitly, "blight" designations are symbolic allusions to the economic and moral worth of people living in blighted areas, perpetuating the notion, not so subtly signaled in the Tennessee Code, that blighted properties somehow cause a degradation of the character for those living in the vicinity. As Alex Abrahams, owner of Ogle's Vacation Motel and the Red Carpet Inn remarked, "this city has a big problem, an epidemic of a problem.... What has the City done to answer the problem of low-income housing?... The people in the blighted buildings they are still people. .. . If we displace all of these people where will they go?" (quoted in Neil 2016).

Abrahams knows something of the symbolic violence that low-wage residents face. Although he describes himself as a "natural country boy," when he immigrated to the United States from Guyana, he first lived in Chicago's Englewood community, where he went to trade school. He didn't like the cold, windy weather in Chicago, so he joined a gospel group and traveled the country, eventually coming to Sevier County, Tennessee. He fell in love with the Smoky Mountains and decided to stay. Abrahams started his real estate career as an OPC (off-premise consultant) for a time-share company, eventually moving into an on-site sales position. Time-share sales can be a lucrative occupation, and this was particularly true in the mid-2000s before the burst of the housing bubble that precipitated the global financial crisis. Working in time-share sales enabled Abrahams to move out of residential motels, save money, buy properties, and enter into Gatlinburg's fiercely competitive real estate market as a property owner and developer. 
When I met Abrahams in the summer of 2016, I found his approach to Gatlinburg real estate development to be somewhat unorthodox, as he seemed to be driven by more than the ethics of growth and profit. Abrahams, having experienced life as a low-wage worker trying to make a stable life in the tourism-based economy, wanted to contribute to a housing solution for Gatlinburg by redeveloping his motels into a mixture of long-term residences and temporary accommodations for tourists. As he explained, "the overnighters will then subsidize long-term housing for low-income workers who make a home here." After purchasing three motels located on East Parkway Road (the Red Carpet Inn, the Roaring Fork Motel and Cottages, and Ogle's Vacation Motel), Abrahams began a process of renovation, replacing flooring, light fixtures, and furniture. In some cases, he had even knocked down walls in order to expand rooms so that residents could have a kitchen.

But that Thursday night at City Hall, Hill and other officials representing the City of Gatlinburg challenged Abrahams's dream of owning motel/ apartment complexes. Even more disconcerting to Abrahams was Hill's announcement that the only redevelopment proposals considered would be those solicited by developers selected by the GRHA board. Abrahams and other real estate developers in Gatlinburg would have no opportunity to propose a project themselves.

\section{Two Proposals for Redevelopment}

The city released letters of interest from two real estate developersLHP Capital, LLC, and Atlantic Land-in July 2016. ${ }^{5}$ In terms of physical changes to the landscape, both letters included plans that would require demolishing many of the buildings in the ten-acre redevelopment district, including the motel properties owned by Abrahams. At the level of discourse, each letter constructed an image of the "low-income tourismindustry worker" that is manifested through subtle language, including moralizing and aestheticizing frames. Here, I analyze key differences in how each letter is oriented in relation to the "low-income tourism-industry worker."

\section{LHP Capital's Letter of Interest}

The letter of interest submitted by LHP Capital, LLC, a firm from Knoxville, Tennessee, detailed their extensive experience in developing affordable housing projects using state and federal financing-specifically the Low-Income Housing Tax Credit (LIHTC). LHP Capital's sixty-six-page letter provides examples of their other development projects, which include two large apartment complexes as well as a large outdoor-gear retailer. The letter then sketches out a process for property acquisition, provides a 
brief analysis of the need for affordable housing, describes contingencies for dealing with existing businesses, and proposes several redevelopment schemes along with a schedule.

The clearest image of the low-income worker appears within the section entitled "Housing," wherein LHP underscores the importance of affordable housing for "building a healthy community" by giving examples of positive outcomes:

When housing is made affordable, families have more finances to help support life necessities, such as food, clothing and education for their children. They can remain in the community, becoming part of the social fabric promoting stability, community, and engagement. (LHP Capital 2016, 43)

At the end of this paragraph, they state what is-when we reflect on the logic of uneven development-a key impetus for creating affordable housing in Gatlinburg. The letter explains that "families and individuals who live and work in the community provide the labor that make the economy grow" (LHP Capital 2016, 43). Elsewhere, LHP repeats this sentiment, at times suggesting that stable, affordable housing impacts the quality of workers in Gatlinburg. They write that "affordable housing is the best asset to attract good, dependable workers. Gatlinburg and all of Sevier County lack quality affordable workforce housing" (LHP Capital 2016, 51). Is such language suggesting that Gatlinburg lacks quality workers as well?

In reality, LHP seems to know little about Gatlinburg's low-income workforce, in terms of traditional demographic information. Lacking this, LHP's letter remains silent regarding the project's potential for securing LIHTC. Instead, they outline a process that includes a pro forma assessment of market-rate housing in relation to affordable housing for Gatlinburg's tourist-industry workforce. They detail an impressive record in securing state and federal financing, specifically mentioning their 100 percent success rate in securing 9 percent LIHTC. Therefore, the tone of LHP's letter was cautiously optimistic about the possibility for securing LIHTC and other government financing-due to their successful track record (LHP Capital 2016).

On page 51 of LHP's letter, they visualize a plan for the redevelopment district. While housing is at the center, they also propose retail spaces, including a much-needed second grocery store near the downtown corridor (as Gatlinburg currently has only one, and it is located far from downtown and far from many low-wage workers' residences). They explain how they will incorporate the Gatlinburg architectural guidelines, "emphasizing ... the mountain village aesthetic" (LHP Capital 2016, 51). With these words, LHP brings to mind the official, touristic vision of Gatlinburg as a quaint 
Appalachian village. This vision, combined with other subtly suggestive phrases, causes the critical reader to ask: "Who are the 'good, dependable workers' included in LHP's vision? Who does not fit in with the scene evoked by the phrase 'mountain village aesthetic'?"

\section{Atlantic Land's Letter of Interest}

The letter of interest submitted by Atlantic Land is less subtle about the potential frictions between low-income community members and the "aesthetics" of touristic space. As with LHP, Atlantic Land's letter begins by describing the expertise of the individuals who make up their team. Unlike LHP, their portfolio of past successful projects includes only commercial retail development, excluding residential projects. The reason for this omission becomes clear in the section entitled "Residential Uses," where it asserts that the redevelopment district is "not ideal for residential use" (Atlantic Land 2016, 16). The letter states: "Although the city is in critical need of workforce housing, this housing should be located off of the main commercial corridor" (16). Atlantic Land's letter suggests that worker housing be located in "transitional zoning between commercial and residential districts" (16). And since the redevelopment district has "over 1,000 linear feet of frontage on East Parkway," their proposal instead centers on the development of "neighborhood serving" commercial retail, also including a much-needed second grocery store (16). Indeed, the letter states that "affordable housing usage in this corridor will have a lasting negative impact on East Parkway" (17).

Countering LHP's optimistic tone with regard to securing LIHTC or other governmental financing, Atlantic Land notes that Gatlinburg workers are not eligible for federal or state housing programs. They write: "The type of housing needed in Gatlinburg will serve both the local employment needs and the specific needs of the J-1 international housing program. J-1 students do not qualify for affordable housing and are typically in the area for a four-month period" (16-17). J-1 summer travel workers are an important subsection of the Gatlinburg workforce, but annually they could not make up more than 7 percent of the total workforce in Sevier County's tourism industry. ${ }^{6}$ Atlantic Land's letter does not acknowledge that most of Gatlinburg's low-income tourism-industry workers are not J-1 visa recipients but rather US citizens and citizens from outside the United States who have longer-term visas or are undocumented.

As with LHP's letter, Atlantic Land also commits to building a development that follows the city's architectural guidelines, thus conforming to the "mountain village aesthetic," in accordance with "the local regional architecture of the Appalachian Mountain area of East Tennessee" (Atlantic Land 2016, 18). As the letter was being submitted, Atlantic Land was in 
the process of completing the Anakeesta commercial development project, which is cited in the letter as an example of successful development. ${ }^{7}$ Once opened, this tourist park (featuring zip lines, a chairlift, retail spaces, and restaurants) would hover above the downtown corridor, with a significant footprint on Parkway Road. Needless to say, it conforms to the mountain village aesthetic with massive log buildings; traditional architecture; shake shingles; and walkways of stone, brick, and wood. At the end of Atlantic Land's letter, Anakeesta is mentioned once more, but this time it appears in a disclosure about their specific interest in this project:

The development style, use, and architectural quality of this project will impact the ultimate look and entry into the Anakeesta project. Atlantic Land has a vested interest in the city, investing over 50 million dollars in the Anakeesta development. The East Parkway Baskins Creek entry is critical to the overall quality and look of the Anakeesta Mountain entry. (Atlantic Land 2016, 19-20)

There is a regime of aesthetic governmentality propagated by the city's architectural guidelines. For Atlantic Land, aesthetics-meaning here the way in which visitors are coaxed to see "Appalachia" in Gatlinburg's spaces-are cast in opposition to the day-to-day lives of Appalachians and low-income workers. In stating that worker housing should be located "off the main commercial corridor," Atlantic Land explicitly places workers in living spaces where they are to remain invisible to tourists (Atlantic Land 2016, 16). Thus, worker housing is "matter out of place" (Douglas 1966), whereas commercial developments that promote a "mountain village aesthetic," such as Anakeesta, belong in downtown Gatlinburg.

\section{Structural Invisibility and the Limits of Redevelopment}

What of these two letters? How do these real estate developers portray workers? And what can we learn about the tensions between developers, workers, and touristic aesthetics? In the first letter, LHP elided the structural invisibility of low-wage workers by emphasizing their success rate with LIHTC funding and affordable housing development. They ignored the complex realities of actual low-income workers by enclosing them within a framework for producing workers that are "good" and "dependable" (LHP Capital 2016, 51). In the second letter, Atlantic Land shows some knowledge of the workforce, but only one group, J-1 summer travel workers, is highlighted-it is silent about the presence of other low-income workers. Across both letters, the knowledge about Gatlinburg's workforce is, at best, partial.

And this brings us to an important question about the redevelopment plan: Would federal and state housing affordability programs meet the 
needs of Gatlinburg's diverse, low-income tourism-industry workforce? Social scientists argue that federally subsidized housing programs, while meeting the needs of many low-income individuals in the United States, must be better prepared to account for the specific needs that arise from various economic, cultural, and historical circumstances (Dickson-Gomez et al. 2008). Such programs require residents to meet a multitude of eligibility requirements, answering questions about their family's demographics, income level, and history of past evictions, as well as any prior convictions. During participant observation in weekly rental residences, I encountered a small but significant portion of low-income tourism-industry workers who were rebuilding their lives after personal crises-domestic violence, death, and/or drug/alcohol addiction. Conviction for a drug-related crime, or even the conviction of a family member, may prevent a potential resident from being eligible. And while immigrants may be eligible in some cases, undocumented immigrants-another significant portion of low-income workers in Gatlinburg's tourism industry-are ineligible. ${ }^{8}$

Most concerning is that Gatlinburg is not a Qualified Census Tract (QCT), meaning that the federal demographics do not indicate a significant presence of cost-burdened residents (HUD 2019). ${ }^{9}$ Without QCT status, Gatlinburg would not qualify for tax credits for an affordable housing development associated with a community revitalization plan (Tennessee Housing Development Agency 2017a). This is likely an unforeseen outcome of low-income workers residing in motels and other weekly rentals. ${ }^{10}$ In other words, the methods employed by the US Census Bureau to identify and spatially map poverty render Gatlinburg's low-income workforce structurally invisible, a situation that can perhaps be attributed to the US Census Bureau not counting motels as residences. ${ }^{11}$

Atlantic Land's warnings about meeting federal housing eligibility requirements must not have troubled the GRHA or the City of Gatlinburg. By early fall of 2016, LHP Capital, LLC, was chosen as the primary developer for East Parkway at Baskins Creek Bypass. I learned about the announcement through a phone call from Alex Abrahams. While he seemed worried that his motels might be threatened, he told me: "I'm just going to keep doing what I'm doing. The City moves slowly."

What Abrahams, the GHRA, Atlantic Land, and LHP Capital, LLC, could not foresee were the events of November 28, 2016: A devastating wildfire moved from the Great Smoky Mountains National Park into the city. The fire killed fourteen people and destroyed nearly twenty-five hundred structures, including approximately eleven hundred homes (Knoxville News-Sentinel, December 31, 2016). ${ }^{12}$ And although the East Parkway at Baskins Creek Bypass District remained unscathed, the GHRA's plans would inevitably change. 


\section{Conclusion: Furthering the Crisis after November 28, 2016}

The fire's impact on housing cannot be underestimated. While most residential motels survived the fire, four motels had severe fire damage, and are no longer fit for residency. Indeed, after the fire, a great number of roads in Gatlinburg had no houses left at all, only the charred squares where houses had once stood. Throughout 2017, Gatlinburg's housing market experienced unprecedented demand. In addition to the ongoing demand for tourist cabins, there was a need for housing the construction workers assisting with rebuilding projects and newly homeless fire victims, as well as low-income workers who typically lived in residential motels and other weekly rentals. Since the fire, even the cheapest residential motels have increased in price. The Grand Prix Motel, for example, a residential motel located on Ski Mountain Road, was \$125 per week during summer 2016, but by the end of January 2017, it was $\$ 225$ per week.

On January 27, 2017, I received an email from Abrahams letting me know that the East Parkway at Baskins Creek Bypass District project had been suspended. Specifically, LHP advised the City that the project was "not feasible at this time" and withdrew their proposal (Hill 2017). Later, we learned that, in November of 2016, LHP explained to city officials that they were "experiencing difficulties in matching housing quality expectations with the cost of land and rental housing development" (quoted in Neil 2018). So, while the fire likely played a significant role in halting the redevelopment project, there were other factors. In Dave Hill's email to the GRHA, he acknowledged that the fire complicated the pace with which redevelopment projects will take place, stating that the City will "reassess needs and priorities for the upcoming several months to ensure resources are being properly focused towards the recovery and rebuilding efforts of the community" (2017).

A positive outcome of the fire is that it has further galvanized support among city and county officials for developing affordable housing. The Sevier County Economic Development Council issued a study soon after the fire, detailing housing needs relative to employment, wages, and vacancy rates. Later in 2017, new tax credits were directed toward wildfire recovery (Tennessee Housing Development Agency 2017b). In response, Sevier County submitted six applications to the Tennessee Housing Development Agency for LIHTC projects. In July 2017, it was announced that an eighty-unit complex called Watson Glades Place would be built, using LIHTC funding. Ground was broken on July 31, 2018, and the project is slated for completion in December 2019-although when I visited in July 2019, no visible construction had begun. 
It is significant that the proposed solutions have been to invest in affordable housing, and not in the workers themselves. Affordable workforce housing (whether residential motels or LIHTC-funded apartments) makes possible the wage conditions that produce profitability for the tourism industry. To put it another way, it is not simply that low wages cause workers to live in cheap residential motels and other weekly rentals-rather, weekly rental residences, as a form of affordable housing, have enabled business owners to continue to pay wages that allow them to maintain profits, without creating a crisis in homelessness. Will it be possible to close the gap between rents and wages - to mitigate the impacts of uneven development on Gatlinburg's most vulnerable populations?

Currently, there are no proposals for developing workforce training or savings programs - and, even less likely, an increase in wages in order to meet the standard of living in an expensive tourist town. It is doubtful that a minimum wage increase, for example, would gain much traction among state and local politicians, or with an economically uncertain public concerned that such an increase would inflate the cost of day-to-day services and/or raise the unemployment rate. Furthermore, the onslaught of neoliberalism, which has transformed Appalachian industries (Gaventa, Smith, and Willingham 1990), has created a surplus labor market that is always waiting as a reserve (Smith 2011), thus employees are vulnerable when they try to advocate collectively for higher wages and/or benefits.

Balancing housing needs with the high cost of land and development and the low wages of tourism-industry workers is deeply challenging. Terming the city's housing situation a "crisis," Gatlinburg's mayor, in full partnership with the city's commissioners and city manager, has been exploring other options, such as a "payment in lieu of taxes" program that would alleviate property taxes for ten to twenty years (Gaines 2018). But the reality is that Gatlinburg's workforce is not homogenous-it is comprised of J-1 summer travel workers, who are only there intermittently, and locally rooted workers who deal with fluctuating wages year-round. Until federal, state, or local governments recognize the special circumstances that tourismbased communities like Gatlinburg face, their funding programs will probably not fit the needs of a diverse tourism-industry workforce. In the end, investments in land and development are simply out-of-balance with the rents of long-term housing for low- and middle-income tourism-industry workers. Even so, Gatlinburg's tourism industry requires the labor of these individuals, therefore affordable housing is critical to the sustainability of the tourism industry. Will Gatlinburg resolve this catch-22? In the near future, it may be up to individual developers (like Abrahams) to partner with the City of Gatlinburg to advance creative solutions for addressing Gatlinburg's housing needs. 


\section{Notes}

1. All quotations and other circumstantial information, unless otherwise cited, were taken from field notes.

2. When "City" is used (as opposed to "city"), I am referring to the actions taken by the City of Gatlinburg as a governmental entity.

3. I place "Appalachia" in scare quotes in order to denote this use as a social construct produced through visual rhetoric in a specific place and time. I echo Obermiller and Maloney (2016), who acknowledge the uninformed ways the phrase "Appalachian Culture" is (mis) used. I take issue with the notion of a singular "Appalachian" aesthetic.

4. The ability of the GRHA to set the price of "blighted" lands purchased and sold for redevelopment is supported by the Tennessee Code, Section 13-20-204 and 13-20-210.

5. Both LHP Capital, LLC, and Atlantic Land have partnerships with familiar names and faces in Sevier County real estate development.

6. This rough estimate was calculated by dividing the number of 2018 recipients of the J-1 Summer Work Travel visa within the state of Tennessee $(1,797)$ by 24,335 , which is the number of Sevier County employees working within private tourism-oriented industries in 2018. I chose to use "accommodations and food" $(15,710)$ and "retail trade" $(8,625)$, as they commonly employ J-1 workers. Because J-1 numbers are not available at the level of city or county, the 7 percent figure is an overestimate. The actual percentage of J-1 workers in Gatlinburg is smaller. For references, see US Department of State (2018); US Bureau of Labor Statistics (2018).

7. In 2015, Robert Bentz bought seventy-two acres of land in Gatlinburg, constructing a commercial development called "Anakeesta," a Cherokee term meaning "a place where balsam trees grow" (see Farrell 2015). Located near the redevelopment district, Anakeesta opened in 2017 and offers outdoor amusements, retail, and food accommodations (Farrell 2015).

8. This is according to the "Housing Choice Voucher Program Guidebook," which stipulates eligibility for noncitizens with documentation (HUD 2019).

9. Qualified Census Tracts (QCTs) are areas where there is a poverty rate of over 25 percent and/or where half of the households make below 60 percent of the area median gross income (HUD 2020).

10. For example, the US Department of Housing and Urban Development (HUD) draws from the American Community Survey (ACS) for calculating QCT status, which randomly selects housing unit addresses (not commercial addresses, i.e., motels).

11. This is echoed in a Sevier County Economic Development Council-funded study in a discussion about substandard housing: "Hotels are not included in the Census Bureau data for substandard housing" (Hodges \& Pratt Company 2017, 37).

12. See Sevier County Structure Status Map at http://www.arcgis.com/apps/Public Information/index.html?appid=8c18c70f55ac4f81b683454fc7573d76.

\section{References}

Amason, J. Hope. 2015. Uncertain lives: Neoliberalism and the shaping of home among service workers in Gatlinburg. North American Dialogue 18 (1): 1-14.

Atlantic Land. 2016. Letter of interest: East Parkway at Baskins Creek redevelopment proposal. July 11.

Billings, Dwight B., and Kathleen M. Blee. 2000. The road to poverty: The making of wealth and hardship in Appalachia. Cambridge, UK: Cambridge University Press.

City of Gatlinburg. 2008. Architectural guidelines for the commercial corridor. April 18. https:/ / www.gatlinburgtn.gov/planning/planning\%20files/Gatlinburg\%20Architec tural\%20Guidelines.pdf.

—_ 2016. East Parkway at Baskins Creek Bypass District: Redevelopment and Urban Renewal Plan project number 1. March 8. 
Dickson-Gomez, Julia, Mark Convey, Helena Hilario, A. Michelle Corbett, and Margaret Weeks. 2008. Structural and personal factors related to access to housing and housing stability in urban drug users in Hartford, Connecticut. Contemporary Drug Problems 35 (1): 115-52.

Douglas, Mary. 1966. Purity and danger: An analysis of concepts of pollution and taboo. London: Routledge.

Eller, Ronald D. 2008. Uneven ground: Appalachia since 1945. Lexington: University Press of Kentucky.

Farrell, Jeff. 2009. The 'motel people': Temporary lodging permanent for some. Mountain Press, November 15.

- 2015. Hotel, adventure park, and tram on tap for Gatlinburg. Mountain Press, August 24. 2016. Landlord faces new charges. Mountain Press, October 25.

Fritsch, Al, and Kristin Johannsen. 2004. Ecotourism in Appalachia: Marketing the mountains. Lexington: University Press of Kentucky.

Gaines, Jim. 2018. Incentives help ease shortage of affordable housing in Sevier County. Knoxville News-Sentinel, August 1.

Gatlinburg Convention and Visitors Bureau. 2017. Gatlinburg vacation guide. https:/ /www .gatlinburg.com/downloadable-guides / (accessed March 2017).

Gaventa, John. 1980. Power and powerless: Quiescence and rebellion in an Appalachian valley. Urbana: University of Illinois Press.

Gaventa, John, Barbara Ellen Smith, and Alex Willingham. 1990. Communities in economic crisis: Appalachia and the South. Philadelphia: Temple University Press.

Ghertner, Ash. 2015. Rule by aesthetics: World-class city-making in New Delhi. Oxford, UK: Oxford University Press.

Harvey, David. 2014. Use value and exchange value. In Seventeen contradictions and the end of capitalism, 15-24. London: Profile Books.

Hill, David. 2017. Email to Gatlinburg Housing and Redevelopment Authority (GRHA), January 27.

Hodges \& Pratt Company. 2017. Market study: Sevier County housing needs. May 25. https:/ / documentcloud.adobe.com/link/track?uri=urn\%3Aaaid\%3Ascds\%3AUS\%3A06dae28f $-551 \mathrm{e}-46 c c-b b e a-a f 131283708 b$.

Johnson, Greg. 2016. Tourism good for jobs, wages in Sevier County. Knoxville News-Sentinel, September 7.

Kennedy, Coulter, Rushing, and Watson, LLC. 2008. Priority Gatlinburg: An implementation plan for the Gatlinburg vision. Chattanooga, TN.

Lewis, Helen Matthews, Linda Johnson, and Donald Askins, eds. 1978. Colonialism in modern America: An Appalachian case. Boone, NC: Appalachian Consortium Press.

LHP Capital, LLC. 2016. Letter of interest: East Parkway at Baskins Creek redevelopment proposal. July 15.

Martin, C. Brenden. 2007. Tourism in the mountain south: A Double-edged sword. Knoxville: University of Tennessee Press.

Neil, Juli Watson. 2016. Redevelopment hearing attendees express frustrations, concerns. Mountain Press, February 28.

. 2018. 'Burg could work to attract affordable housing. Mountain Press, September 18.

Obermiller, Phillip J., and Michael E. Maloney. 2016. The uses and misuses of Appalachian culture. Journal of Appalachian Studies 22 (1): 103-12.

Smith, Gavin. 2011. Selective hegemony and beyond, populations with "no productive function": A framework for enquiry. Identities: Global Studies in Culture and Power 18 (1): 2-38.

Smith, Michael. 1989. Behind the glitter: The impact of tourism on rural women in the Southeast. Lexington, KY: Southeast Women's Employment Coalition.

Smith, Neil. 2008. Uneven development: Nature, capital, and the production of space. 3rd ed. Athens: University of Georgia Press. 
Southern Poverty Law Center. 2014. Culture shock: The exploitation of J-1 cultural exchange workers. https:/ /www.splcenter.org/20140201/culture-shock-exploitation-j-1-cultural -exchange-workers (accessed December 10, 2019).

Tarus, Lyndsay, Mary Hufford, and Betsy Taylor. 2017. A Green New Deal for Appalachia: Economic transition, coal reclamation costs, and bottom-up policymaking, Part 2. Journal of Appalachian Studies 23 (2):151-69.

Taylor, Betsy, Mary Hufford, and Kendall Bilbrey. 2017. A Green New Deal for Appalachia: Economic transition, coal reclamation costs, and bottom-up policymaking, Part 1. Journal of Appalachian Studies 23(1): 8-28.

Tennessee Housing Development Agency. 2017a. Low-income housing tax credit 2017 QAP. January 24. https://s3.amazonaws.com/thda.org/Documents/Business-Partners /Multi-Family-Developers/LIHTC-Program/Allocations-QAPs-Statistics /2017-QAP -AMENDED-01.29.2020-CLEAN.pdf.

. 2017b. Sevier County eligible to apply for Rebuild and Recover funds. https://thda .org/news-media/sevier-county-eligible-to-apply-for-rebuild-and-recover-funds.

US Bureau of Labor Statistics. 2017. Local area unemployment data for 1990-2017. Sevier County, TN. https:/ / www.bls.gov/lau/ (accessed March 2017).

2018. Quarterly census of employment and wages. Sevier County, TN. https:/ / www .bls.gov/cew / (accessed February 20, 2020).

US Census Bureau. 2010. Census 2010. https://factfinder.census.gov/faces/nav/jsf/pages /community_facts.xhtml (accessed November 16, 2019).

US Department of Housing and Urban Development (HUD). 2019. Housing choice voucher program guidebook. https://www.hud.gov/program_offices/public_indian_housing /programs/hcv/guidebook.

- 2020. 2019 and 2020 small DDAs and QCTs map: Office of Policy Development and Research. https://www.huduser.gov/qct/qctmap.html (accessed April 24, 2020).

US Department of State. 2018. Exchange visitor program: J-1 basics: Facts and figures. https:/ / j1visa.state.gov/basics/facts-and-figures/ (accessed February 20, 2020). 